\title{
Quantitative Phytochemical Composition and Bioactive Constituents of Ethanolic Extract of Phyllanthus amarus (schum. et thonn) Leaves
}

\author{
E. O. Oshomoh and O. Uzama-Avenbuan
}

\begin{abstract}
Herbs are used in the treatment of several human ailment and diseases. The quantitative phytochemical composition, bioactive constituents of ethanol extract of Phyllanthus amarus leaves were determined. The quantitative phytochemical analysis of ethanol extract of Phyllanthus amarus found to be present in this study includes phenol, flavonoid, saponin, tannin and alkaloid. The total content of phenol is $73.163 \mu \mathrm{g} / \mathrm{ml}$, flavonoid is $137.27 \mu \mathrm{g} / \mathrm{ml}$, tannin is $3.581 \mu \mathrm{g} / \mathrm{ml}$, alkaloid is $30.1 \%$ and saponin is 34.822 ppm. The GC-MS analysis of bioactive constituents of the ethanol extract of Phyllanthus amarus leaves resulted in $\mathbf{4 4}$ compounds which have diverse use. The various bioactive compounds present in $P$. amarus confirm its uses for the treatment of various ailments and diseases by traditional practitioners.
\end{abstract}

Index Terms - Bioactive constituents, Phyllanthus amarus, phytochemical constituents, traditional practitioners.

\section{INTRODUCTION}

Phyllanthus amarus, of the family Euphorbiaceae, made up of 6500 species in 300 genera, about 200 are American, 100 are African, 70 are Madagascar and the remaining are Australian and Asian [1]. The name 'Phyllanthus' refers to "leaf and flower" in which the flower and fruit become one with the leaf [1].

$P$. amarus consists of different classes of important medicinal organic compounds such as alkaloids, polyphenols, flavonoids, sterols, hydrolysable tannins (Ellagitannins), major lignans, triterpenes, and volatile oil. Many lignans such as phyllanthin (bitter component) and hypophyllanthin (nonbitter component) have been isolated from the plant [3].

$P$. amarus contains secondary metabolites such as alkaloids, flavonoids, triterpenes, hydrolysable tannins (Ellagitannins), major lignans, sterols, polyphenols and volatile oil. The lively constituents of $P$. amarus are lignans (phyllanthin, hypophyllanthin, nirurin niranthin, phyltetralin, niranthine, nirtetralin etc.) [4], [5], flavonoids (quercetrin, quercetin, rutin, gallocatechin, phyllanthusiin and kaempferol [6].

A phytochemical screening of extract of methanol obtained from the entire plant of $P$. amarus has shown that six bioactive lignans as earlier presented by [4]. Also, according to [7] P. amarus revealed the presence of high level of saponins and tannins but with low percentage of cyanogenic glycosides.

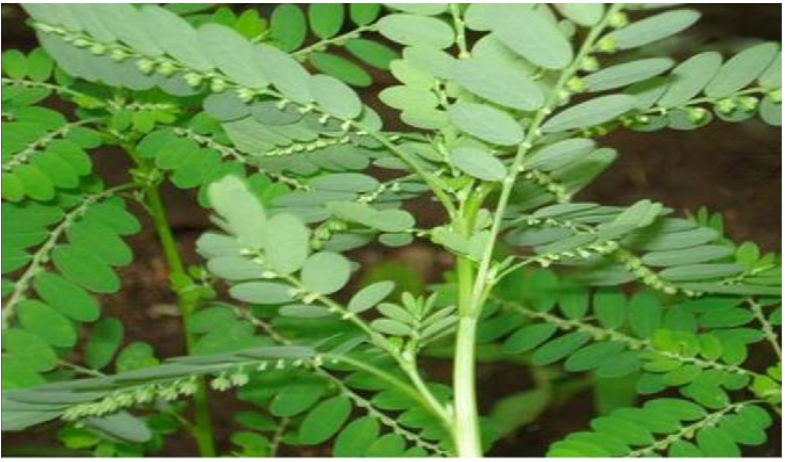

Fig 1. Phyllanthus amarus plant [2].

By the findings of [8], P. amarus contains antiurolithic property that can be used to treat gallstones, kidne and, other kidney related problems.

This study aimed at investigating the quantitative phytochemical composition and chemical compounds of ethanolic extract of $P$. amarus leaves.

\section{MATERIALS AND METHODS}

\section{A. Collection of Plant Sample and Treatment}

The plant sample of Phyllanthus amarus were obtained from the vicinity of University of Benin and identified by Dr. H.A. Akinnibosun of the Plant Biology and Biotechnology Department, University of Benin. Benin City, Nigeria.

\section{B. Treatment of plant sample}

The plant sample was thoroughly washed in clean water, air dried at room temperature for several days, ground into fine powder with electrical mechanical engine. Powdered leaves sample was stored in an air-tight container further use.

\section{Extraction procedure}

About two hundred and sixteen eight grams (216 g) of the ground leaves was exhaustively extracted with $500 \mathrm{ml}$ of ethanol using a Soxhlet extractor equipped with a reflux condenser for about 8 hours. The extract was concentrated using rotary evaporator on a water bath $\left(50{ }^{\circ} \mathrm{C}\right)$ to give the crude extracts.

D. Quantitative phytochemical composition of the extract

1. Determination of phenolic content

The amount of total phenolics in the plant extract was determined using standard method prescribed by [9] with 
slight modification using tannic acid as a standard.

\section{Determination of alkaloids content}

The alkaloid content was determined using the method prescribed by [10].

\section{Determination of flavonoid content}

The flavonoid content was examined in triplicate aliquots of the homogenous cabbage extract (1.5 g) [11]. Thirtymicrolitre aliquots of the extract was used for flavonoid examination. Samples were diluted with $90 \mu \mathrm{l}$ methanol, $6 \mu \mathrm{l}$ of $10 \%$ Aluminum chloride $\left(\mathrm{AlCl}_{3}\right)$. Six microlitre of $1 \mathrm{~mol} / 1$ Sodium acetate $\left(\mathrm{CH}_{3} \mathrm{CO}_{2} \mathrm{Na}\right)$ was added and lastly $170 \mu \mathrm{l}$ of methanol was added. The absorbance was read after 30 mins at $415 \mathrm{~nm}$. Quercetin was used as a reference to calculate the flavonoid content (Ug Qe/g).

\section{Estimation of Saponins content}

The estimate of total saponins content was determined by the method according to [12] based on vanillin-sulphuric acid colorimetric response with some modifications.

\section{Determination of Tannin content}

About $0.20 \mathrm{ml}$ of sample was added to $20 \mathrm{ml}$ of $50 \%$ methanol and placed in a water bath at $77{ }^{\circ} \mathrm{C}-80{ }^{\circ} \mathrm{C}$ for $1 \mathrm{hr}$ and shaken. The extract was filtered using a double layered Whatman No.1 filter paper and $20 \mathrm{ml}$ of distilled water, 2.5 $\mathrm{ml}$ Folin-Denis reagent and $10 \mathrm{ml} 17 \% \mathrm{Na}_{2} \mathrm{CO}_{3}$ were added and mixed. The mixture was allowed to settle for 20 mins. A series of standard tannic acids solutions were prepared in methanol and their absorbance as well as samples was read after development of colour on a UV/ Visible spectrophotometer at $760 \mathrm{~nm}$. Total tannin content was calculated from calibration curve.

\section{RESULTS}

Table 1 shows the quantity of the phytochemicals present in the plant extract which included $73.163 \mu \mathrm{g} / \mathrm{ml}$ of phenols, $137.27 \mu \mathrm{g} / \mathrm{ml}$ of flavonoids, $3.581 \mu \mathrm{g} / \mathrm{ml}$ of tannins, $30.1 \%$ of alkaloids and $34.822 \mathrm{ppm}$ of saponins. These phytochemicals are useful bioactive agents that have physiological effect in human [13].

Table 2 shows the GC-MS analysis of bioactive constituents of the ethanolic extract of Phyllanthus amarus leaves. The phytochemical constituents present in the alcholic extract of $P$. amarus leaves were identified by GC-MS analysis. The active components with their retention time (RT), molecular formula (MF), molecular weight (MW), peak area (PA) and \% peak area (\% PA) in the extracts of $P$. amarus are presented. From the sample, 44 compounds were identified which includes: 3-Allyloxy-1,2 propanediol, Octanoic acid, 2-Methoxy-4-vinylphenol, n-Decanoic acid, Undecanoic acid, 10-methyl-, methyl ester, Dodecanoic acid, Oleic Acid, Dodecanoic acid, Tetradecanoic acid, 2Pentadecanone, 6,10,14-trimethyl, Cyclopentanetridecanoic acid, methyl ester, n-Hexadecanoic acid, Hexadecanoic acid, ethyl ester, Acetic acid, 2-(2,2,6-trimethyl-7-oxabicyclo[4.1.0]hept-1-yl), propenyl ester, 2,6-Cyclooctadien1-ol, Cyclopropanebutanoic acid, 2-[[2-[[2-[(2pentylcyclopropyl]methyl] cyclopropyl] methyl]cyclopropyl]methyl]-, methyl ester, Phytol, Oleic Acid, 9,12,15-Octadecatrienoic acid, ethyl ester, (Z,Z,Z), 2HBenzo[f]oxireno[2,3-E]benzofuran-8(9H)-one, Stigmasterol, 3-Phenyl-1,3-pentanediol, Cyclopentanone, 2,5-di(1- adamantyl) etc.

The GC-MS chromatogram of the isolated oil given in Figure 1 showed 44 peaks which indicated that it contain 44 compounds. The chemical compounds identified in the oil fraction are presented in Table 2. From the GC-MS analysis as shown in Table 2, the major components detected from the oil isolate of Phyllanthus amarus were Benzamide, N,Ndinonyl-3-methoxymin (6.12\%), Narcissidine, 1,3-diacetyl4,12-dihydro $(8.76 \%)$, alpha.-Tocopherol-.beta.-Dmannoside $(8.64 \%, 5.57 \%$ and $7.37 \%)$, 2-(Adamantan-1ylcarbamoylmethoxy)-N-(1-phenyl-ethyl)-benzamide $\quad(6.27$ $\%)$.

TABLE I: QUANTITATIVE PHYTOCHEMICAL CONTENTS IN ETHANOL EXTRACT OF PHYLLANTHUS AMARUS

\begin{tabular}{ll}
\hline \hline Phytochemicals & Samples (PAE) \\
\hline Phenolic Content $(\mathrm{Ug} / \mathrm{ml})$ & 73.16 \\
Flavonoid Content $(\mathrm{Ug} / \mathrm{ml})$ & 137.27 \\
Tannin Content $(\mathrm{Ug} / \mathrm{ml})$ & 3.58 \\
Alkaloids $(\%)$ & 30.10 \\
Saponin $(\mathrm{PPM})$ & 34.82 \\
\hline \hline
\end{tabular}

PAE = Phyllantus amarus ethanol

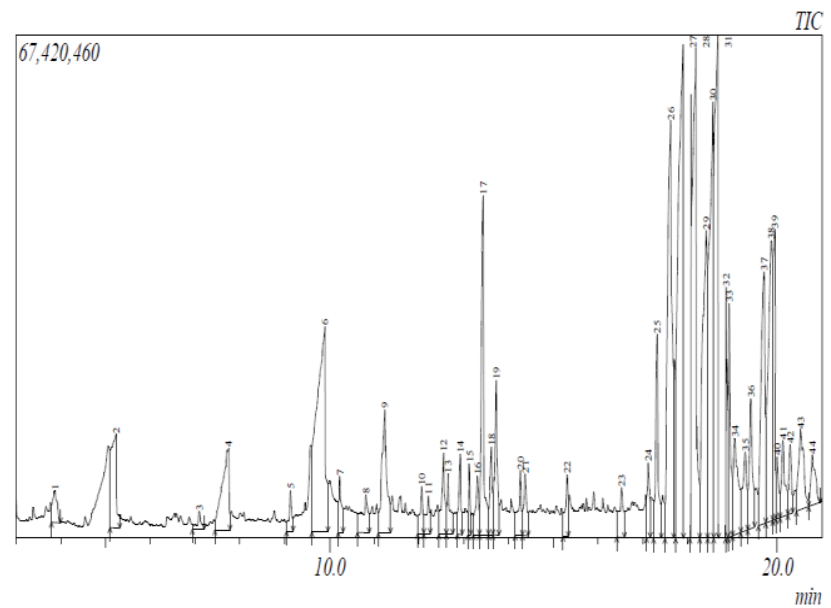

Fig. 2. The total ion chromatogram (TIC) of ethanolic extracts of Phyllantus amarus.

TABLE 2A: GC- MS ANALYSIS OF BIOACTIVE CONSTITUENTS OF THE ETHANOLIC EXTRACT OF PHYLLANTHUS AMARUS LEAVES

\begin{tabular}{lllllll}
\hline SN & Name of Compound & \multicolumn{4}{c}{ Isolated Compounds } \\
& & MF & MW & RT & PA & \%PA \\
\hline 1 & 3-Allyloxy-1, 2 propanediol & $\mathrm{C}_{6} \mathrm{H}_{12} \mathrm{O}_{3}$ & 132 & 3.872 & 29783021 & 0.56 \\
2 & Octanoic acid & $\mathrm{C}_{6} \mathrm{H}_{16} \mathrm{O}_{2}$ & 144 & 5.237 & 106149857 & 2.00 \\
3 & 2-Methoxy-4-vinylphenol & $\mathrm{C}_{9} \mathrm{H}_{10} \mathrm{O}_{2}$ & 150 & 7.092 & 14563982 & 0.28
\end{tabular}

\begin{tabular}{|c|c|c|c|c|c|}
\hline n-Decanoic acid & $\mathrm{C}_{10} \mathrm{H}_{20} \mathrm{O}_{2}$ & 172 & 7.746 & 117832248 & 2.23 \\
\hline Undecanoic acid, 10-methyl-, methyl ester & $\mathrm{C}_{13} \mathrm{H}_{26} \mathrm{O}_{2}$ & 214 & 9.131 & 20542941 & 0.39 \\
\hline Dodecanoic acid & $\mathrm{C}_{12} \mathrm{H}_{34} \mathrm{O}_{2}$ & 200 & 9.896 & 366592106 & 6.92 \\
\hline Oleic Acid & $\mathrm{C}_{18} \mathrm{H}_{34} \mathrm{O}_{2}$ & 282 & 10.229 & 30230291 & 0.57 \\
\hline Dodecanoic acid & $\mathrm{C}_{12} \mathrm{H}_{34} \mathrm{O}_{2}$ & 200 & 10.816 & 46081755 & 0.87 \\
\hline Tetradecanoic acid & $\mathrm{C}_{14} \mathrm{H}_{28} \mathrm{O}_{2}$ & 228 & 11.231 & 125396926 & 2.37 \\
\hline 2-Pentadecanone, 6,10,14-trimethyl- & $\mathrm{C}_{18} \mathrm{H}_{36} \mathrm{O}$ & 268 & 12.060 & 27709373 & 0.52 \\
\hline Cyclopentanetridecanoic acid, methyl ester & $\mathrm{C}_{19} \mathrm{H}_{36} \mathrm{O}_{2}$ & 296 & 12.210 & 26155388 & 0.49 \\
\hline n-Hexadecanoic acid & $\mathrm{C}_{16} \mathrm{H}_{32} \mathrm{O}_{2}$ & 256 & 12.548 & 53681496 & 1.01 \\
\hline Hexadecanoic acid, ethyl ester & $\mathrm{C}_{18} \mathrm{H}_{36} \mathrm{O}_{2}$ & 284 & 12.649 & 35954705 & 0.68 \\
\hline $\begin{array}{l}\text { Acetic acid, 2-(2,2,6-trimethyl-7-oxa- } \\
\text { bicyclo[4.1.0]hept-1-yl)-propenyl ester }\end{array}$ & $\mathrm{C}_{14} \mathrm{H}_{22} \mathrm{O}_{3}$ & 238 & 12.918 & 36302387 & 0.69 \\
\hline 2,6-Cyclooctadien-1-ol & $\mathrm{C}_{8} \mathrm{H}_{12} \mathrm{O}$ & 124 & 13.127 & 21936560 & 0.41 \\
\hline $\begin{array}{l}\text { Cyclopropanebutanoic acid, } 2-[[2-[[2-[(2- \\
\text { pentylcyclopropyl)methyl] cyclopropyl]methy }\end{array}$ & $\mathrm{C}_{23} \mathrm{H}_{42} \mathrm{O}_{2}$ & 374 & 13.307 & 37107577 & 0.70 \\
\hline
\end{tabular}


TABLE 2B: GC-MS ANALYSIS OF BIOACTIVE CONSTITUENTS OF THE ETHANOLIC EXTRACT OF PHYLLANTHUS AMARUS LEAVES

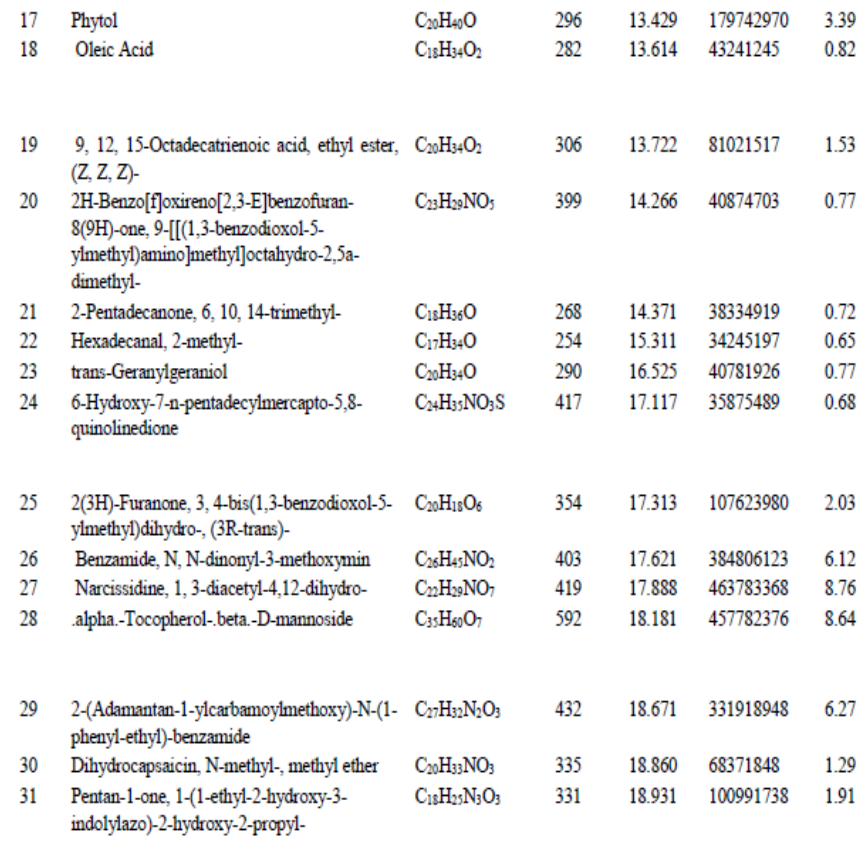

TABLE 2C: GC-MS ANALYSIS OF BiOACTIVE CONSTITUENTS OF THE ETHANOLIC EXTRACT OF PHYLLANTHUS AMARUS LEAVES

\begin{tabular}{|c|c|c|c|c|c|c|}
\hline 32 & $\begin{array}{l}\text { Silane, dimethyl (2- } \\
\text { methylphenoxy)octadecyloxy- }\end{array}$ & $\mathrm{C}_{27} \mathrm{H}_{50} \mathrm{O}_{2} \mathrm{Si}$ & 434 & 19.054 & 96853176 & 1.83 \\
\hline & Ergost-5-en-3-ol, (3.beta.)- & $\mathrm{C}_{28} \mathrm{H}_{48} \mathrm{O}$ & 400 & 19.281 & 68948241 & 1.30 \\
\hline & Stigmasterol & $\mathrm{C}_{29} \mathrm{H}_{48} \mathrm{O}$ & 412 & 19.410 & 90888509 & 1.72 \\
\hline & $\begin{array}{l}\text { 2(3H)-Furanone, 3,4-bis(1,3-benzodioxol-5- } \\
\text { ylmethyl)dihydro-, (3R-trans)- }\end{array}$ & $\mathrm{C}_{20} \mathrm{H}_{18} \mathrm{O}_{6}$ & 354 & 19.707 & 206532749 & 3.90 \\
\hline & $\begin{array}{l}\text { [4-(2,4-Dimethoxybenzyl)piperazin-1-yl]- (2- } \\
\text { methoxyphenyl)methanone }\end{array}$ & $\mathrm{C}_{21} \mathrm{H}_{26} \mathrm{~N}_{2} \mathrm{O}_{4}$ & 370 & 19.861 & 261192755 & 4.93 \\
\hline & $\begin{array}{l}\text { Urea, 1-[4-(chlorodifluoromethoxy)phenyl]- } \\
\text { 3-(3-methoxybenzoyl)- }\end{array}$ & $\mathrm{C}_{16} \mathrm{H}_{13} \mathrm{ClF}_{2} \mathrm{~N}_{2} \mathrm{O}_{4}$ & 370 & 19.946 & 127768841 & 2.41 \\
\hline & $\begin{array}{l}\text { Urea, 1-[4-(chlorodifluoromethoxy)phenyl]- } \\
\text { 3-(3-methoxybenzoyl)- }\end{array}$ & $\mathrm{C}_{16} \mathrm{H}_{13} \mathrm{ClF}_{2} \mathrm{~N}_{2} \mathrm{O}_{4}$ & 370 & 19.998 & 29031757 & 0.55 \\
\hline & 2-Adamantanol, 2-(bromomethyl)- & $\mathrm{C}_{1 !} \mathrm{H}_{l} \geq \mathrm{Br}_{\mathrm{r}} \mathrm{O}$ & 244 & 20.124 & 54408421 & 1.03 \\
\hline 40 & $\begin{array}{l}\text { 2(3H)-Furanone, 3,4-bis(1,3-benzodioxol-5- } \\
\text { ylmethyl)dihydro-, (3R-trans)- }\end{array}$ & $\mathrm{C}_{20} \mathrm{H}_{18} \mathrm{O}_{6}$ & 354 & 20.289 & 37355127 & \\
\hline & 3-Phenyl-1,3-pentanediol & $\mathrm{C}_{11} \mathrm{H}_{16} \mathrm{O}_{2}$ & 180 & 20.525 & 85241759 & \\
\hline & Cyclopentanone, 2,5-di(1-adamantyl)- & $\mathrm{C}_{25} \mathrm{H}_{36} \mathrm{O}$ & 352 & 20.783 & 46675772 & 0.8 \\
\hline
\end{tabular}

\section{DISCUSSION}

The result for the phytochemical composition of $P$. amarus leaf extract showed the presence of phenol, flavonoid, saponins, tannin and alkaloids. The plant is rich in flavonoid, phenol, saponin and alkaloids. This corresponds with the report of [14] in a qualitative determination that reported the presence of alkaloids, flavonoids, phenols and triterpenes in the plant. Phytochemical constituents are secondary metabolites of plants that serve as defense mechanism against predation by lots of microorganisms, insects and other herbivores [15]. These bioactive compounds are known to act by different mechanisms and exercise antimicrobial action. Tannins form an irreversible complex with proline rich proteins resulting in the inhibition of cell protein synthesis. Flavonoids are hydroxylated phenolic compounds known to be synthesized by plants in response to microbial infection and it is not a surprise that are present in vitro as active antimicrobial substances against a wide range of microorganisms. Their action could be due to their ability to form complexes with extracellular and soluble proteins and to form complexes with cell walls of bacteria [15].

Antimicrobial activity of saponin is owned to its ability to cause leakages of proteins and certain enzymes from the cell. The most common biological properties of alkaloids is their toxicity against cells of foreign organism and this property has led to the development of powerful pain killer medications [15].

The levels of alkaloids and saponins present in the leaf of $P$. amarus suggests that the plant might have good blood glucose reducing activities by reducing the absorption of dietary glucose in the gastrointestinal tract and may have marked effects on the modulation of immune system and the prevention of oxidative stress concertedly [16]. The presence of phenols and flavonoids in the extract can help prevent oxidative stress by scavenging free radicals and bioactivation of carcinogens for excretion in the liver [17]. The presence of alkaloids, flavonoids and other phytochemicals in plant has effect on man and has led to development of potent pain killer drugs [18]. This shows that the plant could be very useful in fighting diseases that can lead to cell injury like neuroinflamation due to the presence of free radicals and could also be useful to fight the aging process.

The GC- MS analysis of bioactive constituents of the alcoholic extracts of $P$. amarus leaves resulted in 44 compounds which have diverse use. Compounds having antiinflammatory, antibacterial, antifungal and skin conditioning properties have been identified which includes: 3-Allyloxy1,2 propanediol, Octanoic acid, 2-Methoxy-4-vinylphenol, nDecanoic acid, Undecanoic acid, 10-methyl-, methyl ester, Dodecanoic acid, Oleic Acid, Dodecanoic acid, Tetradecanoic acid, 2-Pentadecanone, 6,10,14-trimethyl, Cyclopentanetridecanoic acid, methyl ester, n-Hexadecanoic acid, Hexadecanoic acid, ethyl ester, Acetic acid, 2-(2,2,6trimethyl-7-oxa-bicyclo[4.1.0]hept-1-yl), propenyl ester, 2,6Cyclooctadien-1-ol, Cyclopropanebutanoic acid, 2-[[2-[[2[(2-pentylcyclopropyl) methyl] cyclopropyl] methyl]cyclopropyl]methyl]-, methyl ester, Phytol, Oleic Acid, 9,12,15-Octadecatrienoic acid, ethyl ester, (Z,Z,Z), 2HBenzo[f]oxireno[2,3-E]benzofuran-8(9H)-one, Stigmasterol, 3-Phenyl-1,3-pentanediol, Cyclopentanone, 2,5-di(1adamantyl) were recoverd from the sample [19].

Fatty acid compounds such as Hexadecanoic acid found in the sample may be active antidiarrhoeal and antimicrobial agent. Methoxy group compounds have been reported to exhibit antimicrobial activity by distorting the surface cell [19]. GC-MS analysis of the present study showed the presence of methylenedioxy compound which have antimicrobial activity. Phytol is an acyclic diterpene alcohol that can be used as a precursor for the manufacture of synthetic forms of vitamin $\mathrm{E}$ [20] and vitamin $\mathrm{K}_{1}$ [21]. In ruminants, the gut fermentation of ingested plant materials liberates phytol, a constituent of chlorophyll, which is then converted to phytanic acid and stored in fats [22]. In shark fish liver it yields pristane. Oleic acid is used as a component foods as triglycerides. Human diet also contains oleic acid as animal fats and vegetable oils. As its sodium salt, oleic acid is a component of soap used emulsifying agent. It is also used as an emollient [23]. In pharmaceuticals, oleic acid is used as an excipient and as emulsifying or solubilizing agent in aerosol 
products [24]. Stigmasterol is used as a precursor making semisynthetic progesterone, a useful human hormone that plays an important physiological role in the regulatory and tissue rebuilding mechanisms related to estrogen effects, as well as acting as an intermediate in the biosynthesis of androgens, estrogens, and corticoids. Urea is destined for use as a nitrogen-release fertilizer [25]. Urea has the highest nitrogen content of all solid nitrogenous fertilizers in common use. 2-Methoxy-4-vinylphenol is an aromatic substance used as a flavoring agent. It is one of the compounds responsible for the natural aroma of buckwheat [26]. The aroma of pure substance was described as: apple, spicy, peanut, and wine-like or clove and curry.

In the production of esters for artificial fruit flavours, and pharmaceuticals, decanoic acid can be used [27].

GC-MS analysis revealed the existence of numerous compounds with different chemical structures. Bioactive compounds present are a proof that $P$. amarus can be used for the treatment of various ailments by traditional practitioners. However, isolation of individual phytochemical constituents should be carried out to find a novel drug or a lead compound.

\section{CONCLUSION}

It has shown that Phyllanthus amarus consists of secondary metabolites that serve as defense mechanism against predation by many microorganisms, insects and other herbivores. It also consists of useful bioactive constituents that serve as anti-microbial, vitamins and flavouring agents.

\section{REFERENCES}

[1] V. Sonia, S. Hitender and G. Munish, "Phyllanthus amarus," A Review, Journal of Pharmacognosy and Phytochemistry, vol. 3, no. 2 , pp. 18-22, 2014

[2] J. F. Morton, "Atlas of Medicinal Plants of Middle America, " Library of Congress Cataloging in Publication Data," Thomas books, pp. 1420, 2008.

[3] X. Mao, L. F. Wu, H. L. Guo, W. J. Chen, Y. P. Cui, Q. Qi, S. Li, W. Y. Liang, G. H. Yang, Y. Y. Shao, D. Zhu, G. M. She, Y. You, L. Z. Zhang, "The genus Phyllanthus: an ethnopharmacological, phytochemical, and pharmacological review," Evid. Based Complement. Alterna. Med., pp. 7584952, 2016.

[4] M. A. Maciel, A. Cunha, F. T. Dantas, and C. R. Kaiser, "NMR characterization of bioactive lignans from Phyllanthus amarus Schum \& Thonn," Journal of Magnetic Resonance Imaging vol. 6, pp. 7682, 2007.

[5] M. Singh, N. Tiwari, K. Shanker, R. K. Verma, A. K. Gupta and M. M. Gupta, "Two new lignans from Phyllanthus amarus," Journal of Asian Natural Products Research, vol. 11, pp. 562-568, 2009.

[6] J. S. Londhe, T.P.A. Devasagayam, L. Y. Foo and S.S. Ghaskadbi, "Antioxidant activity of some polyphenol constituents of the medicinal plant Phyllanthus amarus Linn,'” Redox Rep., vol. 13, pp. 199-207, 2008.

[7] C. U. Igwe, L. A. Nwaogu and C. O. Ujuwondu, "Assessment of the hepatic effects, phytochemical and proximate compositions of Phyllanthus amarus. Department of Biochemistry, Federal University of Technology, Owerri, Imo State, Nigeria," African Journal of Biotechnology Vol. 6, no. 6, pp. 728-731, 2007.

[8] J. R. Patel, P. Tripathi, V. Sharma, N. S. Chauhan, and V. K. Dixit, "Phyllanthus amarus Ethnomedicinal uses phytochemistry and pharmacology," A review, Journal of Ethnopharmacology, vol. 138 , no. 2, pp. 286-313, 2011

[9] V. L. Singleton and J. A. Rossi, B. Kasmani, "Colorimetry of total phenolics with phosphomolybdic-phosphotungstic acid reagents," Am J Enol Vitic, vol. 16, pp. 144-58, 2005.

[10] J. B. Harborne, "Phytochemical Methods," Chapman and Hall, London, pp. 11-21, 1973.
[11] R. Ilahy, C. Hdider, M. S. Lenucci, I. Tlili and G. Dalessandro, "Antioxidant activity and bioactive compound changes during fruit ripening of high-lycopene tomato cultivars," Journal of Food Composition and Analysis, Vol. 24, pp. 588-595. 2011

[12] H. P. Makkar, P. Siddhuraju, K. Becker, "Methods in molecular biology: plant secondary metabolites," Totowa: Human Press; pp. 93 100, 2007.

[13] A. Sofowora, "Medicinal Plants and Traditional Medicine in Africa," 1st Edn., John Wiley and Sons, Chichester, New York, pp. 256, 1982.

[14] P. Saranraj and P. Sivasakthivelan, "Screening of Antibacterial Activity of the Medicinal Plant, Phyllanthus amarus Against Urinary Tract Infection Causing Bacterial Pathogens" Applied Journal of Hygiene, vol. 1, no. 3, pp. 19 - 24. 2012.

[15] T. Arun, B. Senthilkumar, K. Purushothaman and A. Aarthy, "GC-MS Determination of Bioactive Components of Phyllanthus amarus (L.) and its Antibacterial Activity,' Journal of Pharmacy Research, yol. 5 , pp. 9, 2012.

[16] P. A. Okiki, B. P. Olatunji, A. A. S. Egbebi and C. Ojo, "Comparative Study of Nutritional and Phytochemical Composition of Phyllanthus amarus Leaf and Seed," American-Eurasian Journal of Toxicological Sciences, vol. 7 no. 4, pp. 321-327, 2015.

[17] A. K. Khanna, F. Rizvi and R. Chander, "Lipid lowering activity of Phyllantus niruri in hyperlipideamia rats," Journal of Ethanopharmacol, vol. 82, no. 1, pp. 19-22, 2002.

[18] P.C.A. Kam and Liew, (2002). Traditional Chinese herbal medicine and anaesthesia, Anaesthesia, vol.57, no. 11, pp. 1083-1089, 2002.

[19] S. Baluja, S. Chanda and K. Nandha, "Antimicrobial activity of some pyrimidine derivatives in DMF and DMSO" Int Lett Chem Phys Astron. Vol. 56, pp 131-141, 2015.

[20] T. Netscher, "Synthesis of Vitamin E". In Litwack, Gerald. Vitamin E. Vitamins \& Hormones, vol. 76, pp. 155-202, 2007.

[21] A. Daines, R. Payne, M. Humphries and A. Abell, (2003). "The Synthesis of Naturally Occurring Vitamin $\mathrm{K}$ and Vitamin $\mathrm{K}$ Analogues". Current Organic Chemistry, vol. 7, no. 16, pp. 16251634,2003

[22] D. M. Van Den Brink and R. J. A. Wanders, "Phytanic acid: Production from phytol, its breakdown and role in human disease". Cellular and Molecular Life Sciences, vol. 63, no. 15, pp. 1752-1765, 2006.

[23] F. Carrasco, "Ingredientes Cosméticos", in Diccionario de Ingredientes 4 th ed. 2009 , pp. 428.

[24] A. F. Oliveira, D. A. Chunha and L. Ladriere, "In vitro use of free fatty acids bound to albumin: A comparison of protocols". BioFeedback. BioTechniques (Letter to the Editor) vol. 58, pp. 228-33. 2015.

[25] Nomenclature of Organic Chemistry: IUPAC Recommendations and Preferred Names (Blue Book). Cambridge, pp. 416, 860-861, 2013.

[26] D. Janes, D. Kantar, S. Kreft and H. Prosen, "Identification of buckwheat (Fagopyrum esculentum Moench) aroma compounds with GC-MS,' Food Chemistry, vol. 112, pp. 120-124, 2009.

[27] S. D. Hughes, M. Kanabus, G. Anderson,I. P. Hargreaves, T. Rutherford, M. O'Donnell, J. H. Cross, S. Rahman, S. Eaton and S. J. Heales, "The ketogenic diet component decanoic acid increases mitochondrial citrate synthase and complex I activity in neurona cells," Journal of Neurochemistry, vol. 129, no. 3, pp. 426-433, 2014. 